\title{
Demokracja bezpośrednia wobec dażeń separatystycznych. Rozważania nad kategorią referendum niepodległościowego
}

\begin{abstract}
Streszczenie: Celem niniejszego artykułu było ujęcie referendum niepodległościowego w ramach obecnych w nauce definicji i typologii oraz ukazanie głównych wątpliwości dotyczących politologicznych uwarunkowań oraz funkcji referendum niepodległościowego. Referendum niepodległościowe w większości przypadków uchodzi za szczególny instrument demokracji bezpośredniej i kluczowy etap procesu uzyskiwania własnej państwowości przez ruchy etnoregionalistyczne. Należy je zdefiniować jako głosowanie o charakterze powszechnym, w którym obywatele danego terytorium posiadający czynne prawo wyborcze mogą zadeklarować wolę utworzenia nowego państwa poprzez secesję. Referendum niepodległościowe jest pojęciem, w odniesieniu do którego widoczna jest istotna dysproporcja między liczbą badań empirycznych w formie studium przypadku a liczbą studiów o bardziej generalnym charakterze i teoretycznych ambicjach. Kluczowe problemy dotyczące analizy tej kategorii referendów to: określenie procedury referendum - sposobu inicjacji, warunków wstępnych, osób uprawnionych, treści pytania czy interpretacji wyników. Pamiętać należy o możliwości ustrojowego umocowania instytucji referendum, choć jej realizacja podlega wpływowi czynników bieżących oraz taktycznych decyzji politycznych aktorów, tak jak zwykłe głosowania powszechne.
\end{abstract}

Słowa kluczowe: referendum, referendum niepodległościowe, secesja, separatyzm, demokracja bezpośrednia

\section{Wprowadzenie}

D ążenia separatystyczne ruchów etnoregionalistycznych należą do zjawisk nie tylko szeroko obecnych w przekazach medialnych, ale także intensywnie analizowanych w literaturze naukowej. Od przeszło wieku są stałym elementem życia politycznego świata, choć w wyniku różnorodnych czynników stopień mobilizacji tych ruchów zmienia się w czasie, podobnie jak zakres ich postulatów - wiele ruchów etnoregionalistycznych nie dąży do uzyskania własnej państwowości, lecz uznania swojej odrębności poprzez ustrojowo umocowaną autonomię (Konarski, 2008, s. 8-9). Jeżeli celem jest secesja, to w większości przypadków za kluczowy etap procesu uzyskiwania własnej państwowości uchodzi szczególny instrument demokracji bezpośredniej - referendum niepodległościowe. Cele niniejszego artykułu są dwojakie. Po pierwsze, jest nim ujęcie referendum niepodległościowego w ramach obecnych w nauce definicji i typologii. Po drugie, podjęta zostanie próba ukazania głównych wątpliwości dotyczących politologicznych uwarunkowań oraz funkcji referendum niepodległościowego.

\section{Referendum niepodległościowe jako instrument demokracji bezpośredniej}

Referendum stanowi najbardziej rozpowszechnioną formę demokracji bezpośredniej, w ramach której obywatele mogą uczestniczyć w podejmowaniu wiążących de- 
cyzji (Antoszewski, 2002, s. 375). Wśród instrumentów demokracji bezpośredniej najczęściej wylicza się: zgromadzenie ludowe, inicjatywę ludową, referendum, plebiscyt, weto ludowe, recall oraz ewentualnie appellation of sentence (Uziębło, 2009, s. 39-61; Węglarz, 2013, s. 25-50). Podział taki przyjął się w literaturze naukowej. W Polsce typologie referendów są silnie zakorzenione w historii tej instytucji oraz aktualnym krajowym modelu ustrojowym. Najpowszechniej dzieli się je na obligatoryjne i fakultatywne, opiniotwórcze i wiążące (konstytutywne) oraz ogólnokrajowe i lokalne. Czas przeprowadzenia referendum determinuje podział na ratyfikacyjne (przeprowadzone po podjęciu decyzji przez odpowiedni organ władz publicznych) oraz konsultacyjne (przed podjęciem decyzji) (Antoszewski, 2002, s. 376).

Największe watpliwości budzi termin plebiscytu, który interpretowany bywa odmiennie w różnych językach, i można odnieść wrażenie, że w każdym, mimo różniących się definicji, rodzi ogromne problemy (Sen, 2015, s. 10). Dla niektórych referenda i plebiscyty są synonimiczne (Qvortrup, 2014, s. 4; Bogdanor, 1981, s. 143), ale na polskim gruncie najczęściej wskazuje się dwa najpowszechniejsze sposoby rozumienia pojęcia plebiscytu. Po pierwsze, z perspektywy prawa międzynarodowego, jest to rozstrzygnięcie przez mieszkańców danego terytorium w kwestii jego przynależności państwowej. W przeszłości, zwłaszcza w okresie międzywojennym, instytucja plebiscytu sprowadzała się do wyboru przez mieszkańców spornego terytorium między dwoma państwami, co w Polsce z oczywistych przyczyn ma negatywne konotacje. Obecnie plebiscyt częściej dotyczy kwestii secesji (Uziębło, 2009, s. 55). W takim rozumieniu referendum niepodległościowe jest więc jedną z form plebiscytu, choć zarazem może to prowadzić do paradoksalnego wniosku, przy przyjęciu założenia o rozłączności, że referendum niepodległościowe nie jest referendum, skoro plebiscyt jest wymieniany w katalogu instrumentów demokracji bezpośredniej odrębnie od referendum. Drugie rozumienie plebiscytu dotyczy już perspektywy wewnątrzkrajowej i koncentruje się nie tyle na prawnym charakterze czy przedmiocie decyzji, lecz politycznej funkcji. Istotą plebiscytu staje się przede wszystkim nie rozstrzygnięcie kwestii merytorycznej, jak w typowym referendum, ale wyrażenie zaufania określonemu politykowi (Rachwał, 2005, s. 145). Klasycznym przykładem są tutaj referenda w czasach francuskiej V Republiki i rządów de Gaulle'a (Jakubiak, 2012, s. 257-258). W polskim kontekście przykładowo mowa była o plebiscytarnym charakterze referendum w 1946 r. (Schramm, 2009), a w skrajnie szerokim ujęciu każde wybory są ,plebiscytem osób" (Radwan, 2014, s. 19). Spotyka się też podejście, zgodnie z którym plebiscyt ma jednoznacznie negatywne konotacje (Dezso, 2001, s. 265) i nie jest instrumentem demokracji bezpośredniej, ale wręcz jej zaprzeczeniem (Buchi, Braun, Kaufman, 2013, s. 13, 112-114), co wynika z utożsamienia plebiscytu z mechanizmami, w których to wyłącznie rządzący decydują o tym, kiedy i o co zapytać obywateli. Działanie takie kojarzone jest z wykorzystywaniem plebiscytów przez dyktatorów i reżimy autorytarne. Pojawiają się nawet głosy, że plebiscyt to „zdegenerowana forma referendum” (Zoller, 1999, s. 365) lub głosowanie, w którym nie ma „wolności i sprawiedliwości” (Uleri, 1996, s. 4). Choć trudno wyeliminować pojęcie plebiscytu w odniesieniu do opisu historycznych procesów i wydarzeń, to rzadka, nawet jak na warunki nauk społecznych, skala wieloznaczności terminu nakazuje daleko idącą ostrożność w jego stosowaniu.

Typologia, którą zaproponował Lawrence LeDuc, zdaniem autora niniejszego artykułu, w największym stopniu pomaga uporządkować i analizować kategorię referendów. 
LeDuc dzieli referenda na cztery typy, wedle ich przedmiotu - rodzaju spraw, których dotyczą: konstytucyjnych, międzynarodowych, suwerenności oraz polityki publicznej (LeDuc, 2003, s. 13-50). Referenda konstytucyjne dotyczą przyjęcia konstytucji, jej ewentualnych zmian oraz generalnie spraw o randze ustrojowej i fundamentalnej dla systemu politycznego. Przykładem może być tu referendum szwajcarskie z 1991 roku w sprawie obniżenia wieku uzyskania czynnego prawa wyborczego czy polskie referendum z 25 maja 1997 roku. Referenda w sprawach międzynarodowych to obecnie najczęściej referenda dotyczące przystąpienia do Unii Europejskiej czy przyjęcia nowych aktów europejskiego prawa pierwotnego - np. traktatu z Maastricht czy porozumień pokojowych, jak w Irlandii Północnej w 1998 roku. Referenda suwerennościowe (w niniejszym artykule przyjęto taką wersję thumaczenia, podobnie jak w: Kijewska-Trembecka, 2007, s. 225, choć spotyka się też dłuższą formę „referendum w sprawie suwerenności”) dotyczą kwestii terytorialnych, realizacji prawa do samostanowienia narodów, dewolucji czy federacjonalizacji lub secesji. Możemy tutaj wskazać referenda w Quebecu w latach 1980 oraz 1995 czy w Szkocji w latach 1979, 1997 oraz 2014. Kategoria referendów w sprawach polityki publicznej jest najbardziej różnorodna. Mieszczą się w niej referenda dotyczące prohibicji alkoholu (Islandia, 1908 i 1933 roku), wykorzystania energii nuklearnej (w Szwecji w 1980 roku) czy polskie referenda w 1996 roku - o powszechnym uwłaszczeniu obywateli oraz o niektórych kierunkach wykorzystania majątku państwowego. Najbardziej sporny wydaje się podział między referenda konstytucyjne i suwerennościowe. Kwestie dotyczące np. ustroju federacyjnego są przecież bez wyjątku określane w konstytucji i należą do najważniejszych kwestii ustrojowych.

Pojęcie referendum niepodległościowego jest powszechnie wykorzystywane w polskiej nauce (Czachor, 2014, s. 352; Fedorowicz, 2004, s. 71; Kijewska-Trembecka, 2007, s. 288; Korzeniewska-Wiszniewska, 2014, s. 133; Kużelewska, 2002, s. 76; Mikucka-Wójtowicz, 2013, s. 89; Sobczyński, 2013, s. 224), ale trudno dostrzec naukową refleksję nad kategorią takich wydarzeń politycznych. Brak teoretycznych konstrukcji wokół terminu referendum niepodległościowego, czy w ogóle brak analiz dotyczących referendum niepodległościowego jako pojęcia o abstrakcyjnym charakterze, wiąże się prawdopodobnie także $\mathrm{z}$ tym, że jego egzemplifikacje mają miejsce w bardzo różnorodnych, nieprzystawalnych wręcz, kontekstach. Jedne stanowiły element procesu pokojowego, następującego po latach nierzadko krwawego konfliktu, inne to efekt światowych przełomów - rozpadu imperiów, a część ma miejsce w ustabilizowanych demokracjach o wielowiekowych tradycjach. Referendum niepodległościowe stanowi trudny przedmiot badan - występuje rzadko, a dorobek teoretyczny wypracowany w odniesieniu do referendów (bez podziału na typy) wydaje się mało adekwatny do jego opisu i wyjaśnienia. Takie referendum nie może być traktowane jako zwyczajny instrument demokracji bezpośredniej, docelowo wykorzystywany w swoistej synergii z instrumentami demokracji pośredniej.

$\mathrm{W}$ interesującym nas obszarze tematycznym, referendum suwerennościowe jest terminem najczęściej stosowanym (Sen, 2015, s. 9-13), choć jego znaczenie również bywa różnie interpretowane. Niektórzy autorzy wskazują tutaj na istnienie trzech podtypów takiego referendum, w zależności od zakresu suwerenności, którego dotyczy. Referendum niepodległościowe mieści się w zakresie suwerenności pełnej/konwencjonalnej, ale obok tego istnieją referenda dotyczące suwerenności częściowej (partial sovereignty) - czyli 
m.in. autonomizacja, dewolucja, ale także suwerenności dzielonej (shared sovereignty) (Krasner, 2004, s. 108-118). Przykładów tej ostatniej dostarcza integracja europejska, związana z przekazywaniem części uprawnień organizacjom ponadnarodowym (Auer, 2007 , s. 262). W takim podziale pojęcie suwerenności dzielonej bywa czasem zastępowane przez pojęcie suwerenności łączonej (pooled sovereignty) (Germann, Mendez, 2016, s. 19-20). Niektórzy autorzy do powyższego podziału według kryterium zakresu suwerenności dodają podział dotyczący logiki referendum: integracyjnej lub dezintegracyjnej (Germann, Mendez, 2016, s. 8-9). Prowadzi to do wyróżnienia sześciu typów referendów suwerennościowych, gdzie referendum niepodległościowe reprezentuje typ charakteryzujący się logiką dezintegracyjną oraz zakresem suwerenności konwencjonalnej. W ramach tego podtypu mieści się jeszcze kategoria referendów separacyjnych, które autorzy definiują jako prowadzące do odłączenia się od jednego państwa i przyłączenia do drugiego, ale z dominacją logiki „dezitegracyjnej”. Jeżeli dominuje logika integracyjna, to referendum określane jest jako transferowe (przykładowo referendum w Szlezwiku w 1920 r. miało charakter transferowy, zaś w Tyrolu w 1921 r. już separacyjny). Zbliżony charakter i również nie do końca czytelne definicje wykazuje podział Matta Qvortrupa, który opiera się na wykorzystaniu pojęcia referendum etnonarodowego. Autor dzieli je na cztery kategorie, przy wykorzystaniu dwóch kryteriów, takich jak narodowy lub międzynarodowy charakter oraz homogenizująca lub heterogenizująca funkcja (Qvortrup, 2014, s. 10-11). Międzynarodowy charakter wykazują te referenda, w wyniku których mają powstać co najmniej dwa byty państwowe. Homogenizującą funkcję pełnią referenda, które są wynikiem braku akceptacji dla różnic po stronie elit politycznych, co może wydawać się jednak trudne do jednoznacznego stwierdzenia na podstawie dostępnego materiału empirycznego. Referendum niepodległościowe reprezentuje w tym podziale kategorię referendum międzynarodowego i homogenizującego. Wykorzystując powyższe typologie, pamiętać jednak należy o występowaniu referendów wielowariantowych, gdzie głosującym przedstawia się różne opcje ustrojowe - np. obok niepodległości różne formy stowarzyszeń międzynarodowych, jak to miało miejsce w przypadku Puerto Rico (Bartnik, 2013, s. 71-73).

\section{Referendum niepodległościowego - zakres, uwarunkowania i funkcje}

Niezależnie od powyższych zastrzeżeń, można z pewnością stwierdzić, że ze wszystkich różnorodnych typów, referendum dotyczące niepodległości ma największą wagę (Walker, 2003, s. 9) - dotyczy w sposób bezpośredni wszelkich grup społecznych, elit politycznych, mediów, administracji, a nawet państw trzecich. Referendum niepodległościowe wydaje się pozornie łatwe do zdefiniowania, choć jak widać trudniej jest je umieścić w ramach istniejącej siatki pojęciowej i typologii. W niniejszym artykule referendum niepodległościowe traktowane będzie jako głosowanie o charakterze powszechnym, w którym obywatele danego terytorium posiadający czynne prawo wyborcze mogą zadeklarować wolę utworzenia nowego państwa poprzez secesję. Poza głównym obszarem rozważań w niniejszym artykule pozostawiona jest kwestia powstania państwa w wyniku rozpadu innego państwa (dysmembratio), często wyróżniana w nauce prawa międzynarodowego i odróżniana od secesji, choć ocena poszczególnych stanów faktycz- 
nych może rodzić sporne interpretacje, jak w przypadku Jugosławii, gdzie rozpad państwa poprzedzony był secesją. W niniejszym artykule jako secesję uznaje się wszystkie przypadki utworzenia nowego państwa poprzez oddzielenie, gdzie mimo rozpadu da się wyróżnić państwo o statusie sukcesora. Spory rodzić może określenie statusu tzw. nieoficjalnych referendów lub w szczególności takich głosowań jak w Katalonii w 2014 r. Przeprowadzono je wobec wyraźnego sprzeciwu władz państwowych (w tym Trybunału Konstytucyjnego), a sami organizatorzy deklarowali jego konsultacyjny charakter i odstapili od nazwy referendum niepodległościowego, stosując ostatecznie termin ,procesu obywatelskiej partycypacji dotyczącego przyszłości Katalonii” (Muro, Vlaskamp, 2016, s. 18). Rząd kataloński nie podał nawet oficjalnej frekwencji, która szacowana była przez media $\mathrm{w}$ granicach $37-41 \%$ - liczby skrajnie różne od tych powszechnie występujących w referendach niepodległościowych. Mniej wątpliwości rodzić będą praktyki, takie jak internetowe głosowanie w sprawie secesji, przeprowadzone w Wenecji Euganejskiej w 2014 r. przez organizację „Plebiscyt 2013”. Frekwencja w głosowaniu wynosiła, w zależności od źródła, od 3,6\% (podawane przez firmy badające ruch internetowy) do $63,2 \%$ (podawane przez organizatorów) uprawnionych do głosowania.

Kluczowym podziałem w obrębie referendów niepodległościowych jest ich jednostronność lub dwustronność, co w pewnym stopniu determinuje kształt innego podziału: na referenda legalne i nielegalne. Generalnie w doktrynie prawa międzynarodowego, jak i praktyce politycznej, powszechnie zaakceptowane jest stwierdzenie, że nie istnieje prawo do jednostronnej secesji, jeżeli mniejszość zwarcie zamieszkująca dane terytorium cieszy się prawem do samostanowienia wewnętrznego - nie jest dyskryminowana, nie narusza się jej poczucia tożsamości, nie cierpi w wyniku niesprawiedliwej dystrybucji dóbr, i w szczególności nie są naruszane prawa człowieka (Czubocha, 2012, s. 180-181). W warunkach europejskich trzeba też dodać, że koszty jednostronnej secesji, bez zgody rządu centralnego, przy ogromnej roli Unii Europejskiej i NATO dla zapewnienia rozwoju gospodarczego i bezpieczeństwa, mogłyby być ogromne (Sanjaume, 2016a). Problematyczne może być też umiejscowienie referendum niepodległościowego w czasie - czy powinien to być początek procesu ujawnienia woli secesji, czy może dopiero zwieńczenie procesu, gdzie głosowanie odbywa się po długiej debacie i obustronnych ustaleniach dotyczących warunków secesji.

Referenda suwerennościowe miały miejsce już w okresie XV wieku, ale jako początek czasu ich upowszechnienia wskazuje się Rewolucję Francuską w 1789 r. (Sen, 2015, s. 18). Do dziś możemy wyróżnić pięć etapów upowszechnienia tej instytucji (Laponce, 2001, s. 38-40; Germann, Mendez, 2016, s. 11-13). Pierwszy dotyczył rozstrzygania terytorialnych sporów związanych z dynamicznymi przemianami końca XVIII wieku, drugi zaś procesu jednoczenia Włoch. Trzeci okres to rezultat traktatów pokojowych po I wojnie światowej. Czwarty i piąty to pozostałość po rozpadzie imperiów - najpierw kolonialnych, a później komunistycznego. I właśnie dopiero w tych ostatnich dwóch okresach dominowały referenda niepodległościowe, zazwyczaj skutkujące secesja, kiedy wcześniej referenda suwerennościowe prowadziły w większości przypadków do rozstrzygnięcia sporu o terytorium między państwami lub po prostu wchłonięcia przez państwo. Szacuje się, że do dziś miało miejsce około 100 referendów niepodległościowych, z czego 52 dokonało się w ramach procesów po II wojnie światowej - głównie dekolonizacji, 26 po przełomie roku 1989 w wyniku rozpadu 
bloku komunistycznego, a 16 to rezultat procesów decentralizacyjnych (Germann, Mendez, 2016, s. 17).

Należy nadmienić, że referendum nie jest warunkiem koniecznym uzyskania niepodległości, ale również nie jest warunkiem wystarczającym. Zdarzają się sytuacje, gdzie referendum nie było potrzebne lub nawet możliwe do przeprowadzenia (Vidmar, 2013, s. 169). Niezależnie od tego, jego polityczne znaczenie jest ogromne. Pełni istotną funkcję legitymizacyjną - zarówno byt państwowy wobec społeczności międzynarodowej, jak i nowopowstałe instytucje wobec społeczności. Jeżeli mowa ma być o prawie do samostanowienia, podstawą musi być wola ludzi, aby z tego prawa skorzystać - referendum jest najbardziej oczywistym sposobem jej wyrażenia (Radan, 2012, s. 12). Uznaje się je za kluczowy element „właściwej procedury secesji” (Tancredi, 2006, s. 189-190). Jeżeli powstaje intensywny konflikt między zasadą integralności terytorialnej państw a prawem narodu do samostanowienia, to referendum powinno być najbardziej demokratyczną drogą rozstrzygania problemów. Dopuszczalności takiego rozwiązania stawia się jednak kilka warunków: referendum powinno odbywać się w warunkach ustabilizowanego ładu demokratycznego przy zagwarantowaniu zwolennikom i przeciwnikom secesji równych możliwości ubiegania się o poparcie głosujących, bez presji ze strony innych państw i bez wpływania przez nie na przebieg referendum, a zasada referendum powinna być zaakceptowana na terenie całego państwa (Wiatr, 2014, s. 13). Dlatego też często status referendum niepodległościowego determinowany jest przez okoliczności jego prowadzenia.

Obietnica przeprowadzenia referendum niepodległościowego może też, co zaskakujące, pełnić inną funkcję - ograniczać psychologiczny koszt związany z głosowaniem na partię regionalną dążącą do secesji. Silne partie regionalne mają szeroką bazę wyborczą, której istotną część stanowią paradoksalnie przeciwnicy niepodległości lub osoby niezdecydowane $\mathrm{w}$ tej kwestii. Obietnica referendum pozwala partii na próbę przekonania potencjalnego wyborcy, że głos na nią nie jest równoznaczny z głosem za niepodległością, co czyniły m.in. zarówno Partia Quebecka (Parti Québécois) w 1976 r. (Sen, 2015, s. 21) czy Szkocka Partia Narodowa (Scottish National Party) w latach 2007 i 2011. Widać tu sprzeczność z innym zjawiskiem - popularność partii regionalnych postulujących secesję może być traktowana jako miernik legitymizacji tych żądań. W kontekście wyborów w Katalonii w 2015 r. mówiło się nawet o „de facto referendum" (Martí, Cetra, 2016, s. 107-110), same partie włącznie z prezydentem Katalonii Arturem Masem upowszechniały taki sposób interpretacji wyborów. Ale również i w tej sytuacji ocena wyniku „referendum” nie jest jednoznaczna - partie secesjonistyczne zdobyły większość w regionalnym zgromadzeniu z 72 mandatami na 135 możliwych, ale przy poparciu na poziomie $48 \%$ głosów. Obie strony odmiennie interpretowały wynik tego „referendum”, ale warto zwrócić uwagę, że poparcie partii secesjonistycznych było większe niż w przypadku Quebecu czy Szkocji w ostatnich wyborach przed referendami niepodległościowymi. W kontekście szkockiego referendum mówiło się o jeszcze innej zaskakującej funkcji referendum - według niektórych walka o jak najlepszy wynik, tak aby rozmiary porażki były jak najmniejsze, miała na celu wywarcie presji na rząd brytyjski, aby ten zgodził się lub nawet zainicjował proces poszerzenia zakresu dewolucji, czyli przekazania kolejnych kompetencji autonomicznym szkockim instytucjom (Riddoch, 2013). 
Przeprowadzenie referendum niepodległościowego rodzi szereg poważnych wątpliwości, które wymagają uprzedniego określenia: kto jest uprawniony do głosowania, na jakim terenie prowadzi się głosowanie i jakiego terenu dotyczyć ma rozstrzygnięcie, kto jest uprawniony do inicjowania procedury i jakie warunki są konieczne, aby móc ją skutecznie przeprowadzić. Kolejna sfera, która często powoduje zastrzeżenia, to stwierdzenie, kiedy można ponownie poddać kwestię pod referendalne głosowanie - dostrzec można, że praktyka ta działa tylko w jedną stronę, gdy w pierwszym referendum przegrali zwolennicy niepodległości.

Warunkiem, który powszechnie stawia się referendum niepodległościowemu jest jednoznaczność (free of ambiguity) - dotycząca zarówno treści zadawanego pytania, jak i większości popierającej secesję (Vidmar, 2013, s. 195). Nikt nie jest w stanie określić jednak liczbowo, kiedy większość staje się jednoznaczna, wyraźna (clear) - zakładamy, że przy 50,1\% takowej nie ma, przy $80 \%$ istnieje, ale czy przy 55\% lub $60 \%$ jak w Nowej Zelandii w latach 1908-1914 mowa już o jednoznacznej, wyraźnej większości? Czy może zamiast wyższego odsetka głosujących, porównać liczbę zwolenników do liczby uprawnionych do głosowania - np. 40\% w Szkocji w 1979 roku, 45\% jak w Danii do 1953 roku czy 35\% jak w Urugwaju? Słusznie wskazuje się, że wobec braku jasnej definicji „wyraźnej większości” lepsze jest odwoływanie się do zwykłej większości (Laponce, 2001, s. 54). Zwłaszcza że wszelkie progi dotyczące odsetka uprawnionych mogą tworzyć sytuację, gdzie taktycznie uzasadnionym wyborem dla przeciwników faworyzowanego wariantu odpowiedzi może być brak uczestnictwa w wyborach, co w efekcie doprowadzi do obniżenia frekwencji i zniekształconego wyniku referendum - nadreprezentacji jednej ze stron (Aguiar-Conraria, Magalhães, 2010, s. 78-79).

Sposoby wysłowienia pytania w referendum niepodległościowym, wbrew pozorom, bywają bardzo odmienne. Może mieć naturalną i prostą formę, jak w przypadku szkockim, lub rozbudowaną i nie do końca czytelną, jak w przypadku Quebecu. W 1980 roku brzmiało ono „Czy godzisz się, aby rząd prowincji rozpoczął negocjacje z Ottawą w sprawie suwerennego stowarzyszenia Quebecu z Federacją?”, zaś w 1995: „Czy zgadzasz się, żeby Quebec stał się suwerenny, po wcześniejszym wysunięciu w stosunku do Kanady oficjalnej propozycji dotyczącej nowego ekonomicznego i politycznego partnerstwa w zakresie zdefiniowanym przez Prawo 1 i porozumienie podpisane 12 czerwca 1995 roku?" (Kijewska-Trembecka, 2007, s. 212, 223). Pytanie referendalne w Szkocji też przeszło modyfikację - pierwotnie brzmiało: „Czy zgadzasz się z tym, że Szkocja powinna być niepodległym państwem?”, co w opinii Komisji Wyborczej zwiększało możliwość odpowiedzi na tak i w rezultacie przyjęło ostatecznie formę: „Czy Szkocja powinna być niepodległym państwem?”. Negocjacje nad kluczowymi kwestiami szkockiego referendum ukazały dominację motywacji z zakresu politycznej taktyki, w którym strony maksymalizowały szanse swojego zwycięstwa, a wspólnotowa retoryka służyła tylko jako uzasadnienie dla proponowanych postulatów. Kształt porozumienia edynburskiego, podpisanego w 2012 roku przez brytyjskiego i szkockiego premiera, może z jednej strony służyć jako przykład sukcesu - unilateralne referendum wniosłoby w mechanizmy ustrojowe wielką dozę chaosu, a tak obopólne ustalenie podstawowych reguł gwarantowało uszanowanie wyników przez stronę przegraną w referendum (Adam, 2014, s. 58). Z drugiej strony, było to porozumienie przedstawicieli szkockiej i brytyjskiej elity politycznej, a kształt referendum został ustalony bez żadnego udzia- 
łu mechanizmów partycypacyjnych. Warto w tym miejscu przypomnieć politologiczny podział referendów na kontrolowane (zarządzane przez rządzących) i niekontrolowane oraz prohegemoniczne (wzmacniające rządzących) i antyhegemoniczne (wzmacniające opozycje) (Smith, 1976, s. 6).

Zdefiniowanie demos, które podejmuje decyzję w referendum niepodległościowym może być też o tyle trudne, że m.in. w przypadku quebeckim sąd dopuścił jako prawdopodobną możliwość przesunięcia granic między ewentualnym państwem Quebecu a resztą Kanady - domyślnie zmniejszając terytorium Quebecu, co wydawałoby się racjonalne w kontekście zróżnicowanej terytorialnie struktury głosów referendalnych. Prowadziłoby to jednak też do paradoksu - lud wyrażający wolę secesji w referendum to inny lud, niż ten który ją otrzymał (Okolopcic, 2015, s. 272). Pytanie o szkockie demos miało wiele wymiarów, ostatecznie w jego skład weszli także imigranci z krajów UE bez brytyjskiego obywatelstwa, a także 16- i 17-latkowie, a pozostawiono poza jego granicami ogromnie liczną szkocką diasporę i co zastanawiające w kontekście orzecznictwa Europejskiego Trybunału Praw Człowieka - więźniów. Ale również w szkockim przypadku pojawiła się możliwość „kaskady referendów” (Laponce, 2012, s. 124), wolę odłączenia od Szkocji w przypadku jej niepodległości wyrażali przedstawiciele władz szkockich wysp - Szetlandów i Orkadów.

Zaskakiwać może występowanie referendów niepodległościowych w obszarze anglosaskim, kiedy to jedną z definicyjnych cech modelu westminsterskiego według Lijpharta była demokracja czysto przedstawicielska (Lijphart, 2005, s. 138-142), a w kontekście brytyjskim referendum traktowane było przecież często jako zamach na suwerenność parlamentu i niezależność władzy ustawodawczej (Antoszewski, 2002, s. 376). W systemach prawnych Zjednoczonego Królestwa i Kanady brakuje regulacji ustawowej, która określałaby ramy wykorzystania instytucji referendum (Soroka, 2013, s. 207). Z drugiej strony, postawa Kanady i Wielkiej Brytanii, które mimo braku obowiązku prawnego umożliwiły społeczeństwom je zamieszkującym zrealizować pełne prawo do samostanowienia może być traktowana jako wzorzec na przyszłość.

Instytucja referendum jest na świecie regulowana różnorodnie, można wyróżnić co najmniej kilka typów jej ustrojowego umocowania (Winczorek, 2014, s. 146). Referenda są często regulowane w sposób generalny w aktach rangi ustrojowej, ale definicje te zazwyczaj nie obejmują referendum niepodległościowego, które z natury rzeczy jest wydarzeniem wyjątkowym, a nie zwyczajnym elementem funkcjonowania demokracji. Jedyne kraje, które przewidują na poziomie konstytucji procedurę secesji to Etiopia, Liechtenstein oraz St. Kitts i Nevis. Podobnie, ustrojowo przewidziany charakter miało referendum w Czarnogórze w 2006 r. Powszechniejsza jest jednak sytuacja, że referendum niepodległościowe jest wykluczone poprzez konstytucyjne przepisy dotyczące niepodzielności państwa, narodowej jedności czy integralności terytorialnej (Radan, 2012, s. 15) - choć oczywiście mogą być one zmienione jak wszystkie inne przepisy konstytucyjne. Najszerzej w judykaturze do tej kwestii odniósł się Sąd Najwyższy Kanady, który w 1998 r. wykluczył na gruncie kanadyjskiego prawa możliwość jednostronnej secesji przez prowincję, ale wskazał, że uzyskanie niepodległości jest możliwe poprzez procedurę zmiany konstytucji, która zapoczątkowana mogłaby zostać poprzez wspominane wcześniej „wyraźne wyrażenie (clear expression) woli secesji” (Reference, 1998, s. 424) przez obywateli Quebecu. Ewentualne referendum nie wywołałoby, w ta- 
kim ujęciu, żadnych skutków prawnych, ale „legitymizowałoby starania quebeckiego rządu” (Reference, 1998, s. 424) w celu rozpoczęcia negocjacji odnośnie zmiany konstytucji. Warto tutaj dodać, że powinność podjęcia negocjacji w sprawie zmiany konstytucji nie oznacza obowiązku jej rzeczywistego dokonania. Tak jak rząd brytyjski okazał się wrażliwy na żądania wysyłane ze strony Szkocji, tak rząd hiszpański przyjmuje postawę jednoznacznie wrogą i nie podejmuje żadnych, choćby wstępnych, negocjacji odnośnie secesji czy referendum. Wydaje się, że jedyną szansą w aktualnym układzie hiszpańskiego systemu partyjnego jest taki rezultat wyborów krajowych, który spowoduje, że partie regionalne staną się niezbędnym aktorem przy przetargach koalicyjnych. Warto zwrócić uwagę, że referenda niepodległościowe odbywały się w regionach, w których odrębność i autonomiczność była już uprzednio ustrojowo rozpoznana. Rośnie jednak popularność postulatów, które wskazują, aby ewentualnie pojawiające się żądania secesyjne zostały też uwzględnione w modelu ustrojowym (Norman, 2006, s. 201-203), z dokładnie określoną procedurą - można mówić o swoistym ukonstytucyjnieniu secesji (Haljan, 2014, s. 50-52).

Warto w tym miejscu wskazać na istnienie innego ważnego przedmiotu rozważań w kontekście referendum niepodległościowego - pojęcia suwerenności. Jego zakres znaczeniowy zmieniał się dynamicznie wraz z rozwojem procesów globalizacyjnych i w szczególności intensyfikacji integracji międzynarodowej, zwłaszcza w ramach Unii Europejskiej. Zmiana ta miała swoje odzwierciedlenie także podczas referendów niepodległościowych. Partie postulujące niepodległość nie poszukują już zazwyczaj państwowości o nieograniczonej suwerenności (SanJaume, 2016b, s. 21), zwłaszcza samo pojęcie niepodległości staje się coraz trudniejsze do precyzyjnego uchwycenia (Keating, 2015, s. 77). W kampanii przed referendum niepodległościowym w Szkocji wskazywano, że w rzeczywistości Szkoci chcieli więcej możliwości samookreślenia, ale wcale nie oczekiwali państwa narodowego. Pod wpływem premiera Zjednoczonego Królestwa Davida Camerona nie dopuszczono dodatkowych wariantów odpowiedzi w referendum w 2014 roku (np. poszerzenie dewolucji jako alternatywa dla status quo i niepodległości). Rezultatem kampanii referendalnej w szkockim przypadku były dwa, na pierwszy rzut oka sprzeczne zjawiska, z jednej strony nasilająca się polityczna polaryzacja szkockiego społeczeństwa wokół osi sporu o niepodległości, z drugiej zaś granica między wizjami obu stron kampanii stawała się niewyraźna. Zwolennicy niepodległości wskazywali jak wiele z Unii zostanie zachowane, a zwolennicy Unii jak wielkie są perspektywy dla dalszej dewolucji (Adam, 2014, s. 61). Spór dotyczył nie tyle miejsca docelowego (szeroko rozumiany dobrobyt Szkotów), ale metod w dotarciu do niego (Keating, 2015, s. 77) - w takim rozumieniu niepodległość nie jest celem, ale instrumentem. Większe poparcie dla Unii Europejskiej wśród Szkotów niż na pozostałym terenie Zjednoczonego Królestwa także pokazuje jak silnie wielowymiarowe stało się pojęcie suwerenności.

Niezależnie od wyjątkowości przedmiotu referendów niepodległościowych, ich wynik podlega wpływowi bieżących czynników, podobnie jak wybory powszechne. Popularność wizerunków partii politycznych i ich liderów oraz taktyczne decyzje stron prowadzących kampanię referendalną mogą istotnie oddziaływać na ostateczne rozstrzygnięcie (Pammett, LeDuc, 2001, s. 278-279). Rezultat referendum jest trudny do przewidzenia, zwłaszcza że nawet sondaże prowadzone w krótkim czasie przed referendum mogą ukazywać zafałszowany obraz rzeczywistości - jak to miało miejsce w Quebecu 
w 1995 roku oraz w Szkocji w 2014 roku. Chwiejność postaw jest cechą charakteryzująca okres kampanii referendalnych i choć akurat w przypadku kampanii niepodległościowych skala jest relatywnie mniejsza, to nie można tego zjawiska pomijać. Cechą wyróżniająca już same referenda niepodległościowe jest bardzo wysoki poziom zaangażowania obywateli, mierzony głównie frekwencją, przekraczającą w większości przypadków $80 \%$, a nierzadko i $90 \%$ uprawnionych do głosowania.

\section{Uwagi końcowe}

Referendum niepodległościowe jest pojęciem, w odniesieniu do którego widoczna jest istotna dysproporcja między liczbą badań empirycznych, stanowiących zazwyczaj studium przypadku, a liczbą studiów o bardziej generalnym charakterze i teoretycznych ambicjach. W polskiej literaturze naukowej zagadnienie wydaje się $\mathrm{w}$ dużym stopniu pomijane i nie mieści się w popularnych typologiach i modelach. W literaturze zagranicznej też można wskazać na brak czytelności, używa się najczęściej dużo szerszej kategorii referendów suwerennościowych lub referendów etnonarodowych - do ich składu wlicza się na przykład wszystkie referenda dotyczące autonomii, a czasem nawet przystąpienia do organizacji międzynarodowej. Połączenie w jednej kategorii referendów w sprawie niepodległości i autonomii wydaje się zrozumiałe - mają one zazwyczaj wspólną genezę (dążenia etnoregionalistyczne) i czasem przeprowadza się je na tym samym obszarze w swoistej chronologicznej kolejności, gdzie referendum w sprawie autonomii poprzedzać może referendum niepodległościowe. Pomija się jednak w ten sposób fakt, że oba podtypy referendów silnie się od siebie różnia, jeżeli chodzi o przebieg i skutki. Wszystkie łatwo zauważalne, choćby przy pobieżnej analizie, atrybuty referendum niepodległościowego, takie jak bardzo wysoka frekwencja czy silna polaryzacja, nie dotyczą referendów w sprawie autonomii. Wskazuje to na istotną potrzebę dalszych badań dotyczących kategorii referendów niepodległościowych, mimo wskazanych wcześniej problemów związanych z relatywnie niewielką liczbą przypadków i silnym zróżnicowaniem wewnątrz kategorii.

Kluczowe problemy dotyczące analizy tej kategorii referendów to określenie procedury referendum: sposobu inicjacji, warunków wstępnych, osób uprawnionych, treści pytania czy interpretacji wyników. Pamiętać należy o możliwości ustrojowego umocowania instytucji referendum, choć w kwestiach secesji, zarówno na poziomie międzynarodowym, jak i krajowym, ważniejsze niż stan prawny wydają się czynniki polityczne. Przebieg oraz rezultat referendum podlega wpływowi bieżących wydarzeń oraz taktycznych decyzji politycznych aktorów, tak jak zwykłe głosowania powszechne. Ostatnie referenda niepodległościowe wskazują też na problemy z definiowaniem pojęcia suwerenności, co może prowadzić do paradoksalnej konstatacji, że różnica między niepodległością a autonomią jest, zwłaszcza w kontekście europejskim, coraz mniej wyraźna.

\section{Bibliografia}

Adam E. (2014), Self-determination and the Use of Referendums: the Case of Scotland, „International Journal of Politics Culture and Society", t. 27, nr 1. 
Aguiar-Conraria L., Magalhães P. C. (2010), Referendum design, quorum rules and turnout, Public Choice, „Public Choice”, t. 144, nr 1.

Antoszewski A. (2002), Referendum, w: Leksykon Politologii, red. A. Antoszewski, R. Herbut, Wydawnictwo Atla 2, Wrocław.

Auer A. (2007), National referendums in the process of European Integration: Time for change, w: The European Constitution and National Constitutions: Ratification and beyond, red. A. Albi, J. Ziller, Kluwer Law International, Haga.

Bartnik A. (2013), Portoryko - 500 lat historii zależnej, „Ameryka Łacińska. Kwartalnik analitycznoinformacyjny", t. 21, nr 1.

Bogdanor V. (1981), Referendums and separatism, w: The referendum device, red. A. Ranney, American Enterprise Institute for Public Policy Research, Waszyngton-Londyn.

Büchi R., Braun N., Kaufmann B. (2013), Przewodnik po demokracji bezpośredniej. W Szwajcarii i nie tylko, Stowarzyszenie „Obywatele Obywatelom”, Łódź.

Casanas A. E. (2014), Self-determination and the Use of Referendums: The Case of Scotland, „International Journal of Politics, Culture and Society", t. 27, nr 1.

Czachor R. (2014), Abchazja, Osetia Poludniowa, Górski Karabach: geneza i funkcjonowanie systemów politycznych, Instytut Polsko-Rosyjski, Wrocław.

Czubocha K. (2012), Separatyzm etniczny w dobie praw człowieka - nowe wyzwania dla państwa narodowego i społeczności międzynarodowej, Wydawnictwo Adam Marszałek, Toruń.

Daranowski P. (2009), Uznanie niepodległości Kosowa - usankcjonowanie precedensu, w: Księga pamiatkowa ku czci Profesora Jana Białocerkiewicza, t. 2, red. T. Jasudowicz, M. Balcerzak, TNOiK „Dom Organizatora”, Toruń.

Dezso M. (2001), Plebiscites and referendums, w: Direct democracy: The eastern and central European experience, red. A. Auer, M. Butzer, Ashgate, Aldershot.

Farley L. T. (1986), Plebiscites and sovereignty: The crisis of political illegitimacy, Westview Press, Londyn.

Fedorowicz K. (2004), Ukraina w polskiej polityce wschodniej w latach 1989-1999, Wydawnictwo Naukowe Adama Mickiewicza, Poznań.

Germann M., Mendez F. (2016), Contested Sovereignty: Mapping Referendums on Sovereignty over Time and Space, „British Journal of Political Science”, CJO2016.

Haljan D. (2014), Constitutionalising Secession, Hart Publishing, Portland.

Jakubiak Ł. (2012), Referendum jako narzędzie polityki. Francuskie doświadczenia ustrojowe, Księgarnia Akademicka, Kraków.

Keating M. (2015), The Scottish Independence Referendum and after, „Revista d'Estudis Autonomics i Federals", t. 21.

Kijewska-Trembecka M. (2007), Ideologie dqżeń niepodległościowych, Wydawnictwo Uniwersytetu Jagiellońskiego, Kraków.

Komorowski P. (2011), Niepodległe Kosowo, prawo międzynarodowe i prawa człowieka - próba odnalezienia wspólnego mianownika, „Polski Rocznik Praw Człowieka i Prawa Humanitarnego" t. 2.

Konarski W. (2012), Krótkie wprowadzenie do terminologii etnokulturowej, „e-Politikon”, $\mathrm{nr} 2$.

Korzeniewska-Wiszniewska M. (2008), Serbia pod rzqdami Slobodana Miloševicia: serbska polityka wobec rozpadu Jugosławii w latach dziewięćdziesiatych XX wieku, Wydawnictwo Uniwersytetu Jagiellońskiego, Kraków.

Krasner S. D. (2004), Sharing Sovereignty: New Institutions for Collapsed and Failing States, „International Security", t. 29, $\mathrm{nr} 2$.

Kużelewska E. (2002), Wpływ referendum na przemiany prawno-polityczne $w$ wybranych krajach europejskich, w: Unifikacja i różnicowanie się współczesnej Europy, red. B. Fijałkowska, A. Żukowski, Dom Wydawniczy ELIPSA, Warszawa. 
Laponce J. A. (2001), National self-determination and referendums: The case for territorial revisionism, „Nationalism and Ethnic Politics”, t. 7, nr 2.

Laponce J. A. (2012), Language and Sovereignty Referendums: The Convergence Effect, „Nationalism and Ethnic Politics", t. 18, nr 1.

LeDuc L. (2003), The politics of direct democracy: referendums in global perspective, University of Toronto Press, Toronto.

Lijphart A. (2005), Westminsterski model demokracji, w: Przyszłość demokracji. Wybór tekstów, wyb. P. Śpiewak, Wydawnictwo Aletheia, Warszawa.

Martí D., Cetrà D. (2016), The 2015 Catalan election: a defacto referendum on independence?, „Regional\&Federal Studies”, t. 26, nr 1.

Mikucka-Wójtowicz D. (2013), Działalność partii mniejszości narodowych w Republice Serbii w latach 1990-2008, „Annales Universitatis Paedagogicae Cracoviensis. Studia Politologica” XI, t. 138.

Muro D., Vlaskamp M. C. (2016), How do prospects of EU membership influence support for secession? A survey experiment in Catalonia and Scotland, „West European Politics” 7.03.2016.

Norman W. (2006), Negotiating Nationalism: Nation-Building, Federalism, and Secession in the Multinational State, Oxford University Press, Oxford.

Oklopcic Z. (2015), The Anxieties of Consent: Theorizing Secession between Constitutionalism and Self-Determination, „International Journal on Minority and Group Rights”, t. 22.

Pammett J., LeDuc L. (2001), Sovereignty, leadership and voting in the Quebec referendums, „Electoral Studies", t. 20.

Qvortrup M. (2013), The 'Neverendum'?: A History of Referendums and Independence, „Political Insight", t. 4, nr 2.

Qvortrup M. (2014), Referendums and Ethnic Conflict, University of Pennsylvania Press, Filadelfia.

Rachwał M. (2005), Referendum jako forma udziału obywateli w kierowaniu sprawami publicznymi, „Środkowoeuropejskie Studia Polityczne”, t. 6, nr 2.

Radan P. (2012), Secessionist Referenda in International and Domestic Law, „Nationalism and Ethnic Politics", t. 18, nr 1.

Radwan A. (2014), Skarga konstytucyjna z dnia 22 sierpnia 2014 roku, http://www.allerhand.pl/ straznica_konstytucyjna/Skarga_konstytucyjna_dot.art.35_RefLokU_T.Le\%C5\%9Bniak.pdf, 15.04.2016.

Reference re: Secession of Quebec (1998), 161 DLR (4th) 385.

Ridoch L. (2013), Uncertainty is a starting point too, „The Scotsman” 17.06.2013, http://www.scotsman.com/news/lesley-riddoch-uncertainty-is-a-starting-point-too-1-2968882, 1.04.2016.

Sanjaume-Calvet M. (2016a), Catalonia: From Secessionism to Secession?, 15.01.2016, http://www.e-ir. info/2016/01/15/catalonia-from-secessionism-to-secession/, 16.04.2016.

Sanjaume-Calvet M. (2016b), Quebec, Scotland and Catalonia: How secessionist political parties legitimize political independence, http://paperroom.ipsa.org/papers/paper_13615.pdf, 16.04.2016.

Schramm T. (2009), Tradycje polskiego parlamentaryzmu w XX wieku. W 90. rocznice pierwszych wyborów parlamentarnych w odrodzonej Polsce, http:/www.senat.gov.pl/prace/komisje-senackie/konferencja,2,6668,inauguracja-roku-polskiej-demokracji.html, 15.04.2016.

Sen I. G. (2015), Sovereignty Referendums in International and Constitutional Law, Springer, Zurych.

Smith G. (1976), The functional properties of referendum, „European Journal of Political Research”, t. 4 , nr 1 .

Sobczyński M. (2013), Zmiany polityczne, terytorialne i spory graniczne w Europie ŚrodkowoWschodniej po 1989 r., w: Studia nad Geopolityka XX wieku, Prace Geograficzne, red. P. Eberhardt, Instytut Geografii i Przestrzennego Zagospodarowania im. Stanisława Leszczyckiego PAN, Warszawa. 
Soroka T. (2013), Quebecka lekcja dla Szkocji. Prawne i polityczne podstawy organizacji referendów niepodległościowych w Szkocji i Quebecu, w: Konstytucjonalizm w państwach anglosaskich, red. A. Zięba, Wydawnictwo Uniwersytetu Jagiellońskiego, Kraków.

Tancredi A. (2006), A Normative 'Due Process' in the Creation of States Through Secession, w: Secession: International Perspectives, red. M. G. Kohen, Cambridge University Press, Cambridge.

Uleri P. V. (1996), Introduction, w: The referendum experience in Europe, red. M. Gallagher, P. V. Uleri, Macmillan Press Ltd, Houndmills.

Uziębło P. (2009), Demokracja partycypacyjna, Centrum Badań Społecznych, Gdańsk.

Vidmar J. (2013), Democratic Statehood in International Law: The Emergence of New States in PostCold War Practice, Hart Publishing, Portland.

Walker M. (2003), The Strategic Use of Referendums: Power, Legitimacy, and Democracy, Palgrave Macmillan, Basingstoke.

Węglarz B. (2013), Ewolucja lokalnej demokracji bezpośredniej w Polsce po 1989 roku, Księgarnia Akademicka. Uniwersytet Pedagogiczny im. Komisji Edukacji Narodowej, Kraków.

Wiatr J. (2014), Samostanowienie narodowe - dylematy prawne i polityczne, „Europejski Przegląd Prawa i Stosunków Międzynarodowych”, t. 31, nr 4.

Winczorek P. (2014), Kilka uwag o polskich referendach, „Ruch Prawniczy, Ekonomiczny i Socjologiczny", Rok LXXVI, z. 2.

Zoller E. (1999), Droit Constiutionnel (vol. 2), PUF, Paris.

\section{Direct democracy towards separatist aspirations. Considerations on the category of the independence referendum}

\section{Summary}

Summary: The aim of this article was to present the referendum on independence within the framework of the current definitions and typologies of referendum, and to present the main doubts concerning the political conditions and the function of the independence referendum. The referendum on independence in most cases is considered to be a particular instrument of direct democracy and a key step in the process of gaining statehood by the ethno-regional movements. Such a type of referendum should be defined as popular vote in which citizens (with voting rights) of a certain territory may declare their will to establish a new state through secession. The independence referendum is a concept in relation to which there is a significant disproportion between the number of empirical studies in the form of a case study and the number of studies of more general character and theoretical ambitions. The key issues concerning the analysis of this category of referenda are: the referendum procedure - the way of referendum initiative, the preconditions, the persons entitled, the content of the question or the interpretation of the results. It is important to remember about the possibility of a constitutional regulations of referendum, although its implementation is influenced by current factors and tactical political decisions by actors, just like ordinary public votes.

Key words: referendum, independence referendum, secession, separatism, direct democracy 
